\title{
POSSIBILITIES TO QUANTIFY THE IMPACT OF COHESION POLICING AT THE LEVEL OF THE EU STATES
}

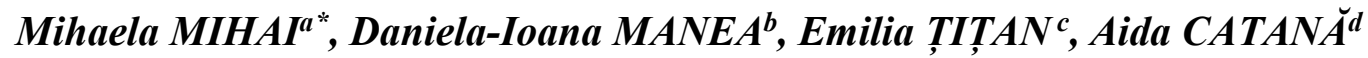 \\ ${ }^{a, b, c, d}$ Bucharest University of Economic Studies, Romania
}

DOI: $10.24818 / \mathrm{IMC} / 2020 / 01.19$

\begin{abstract}
The Structural and Cohesion Funds have evolved with the need for states for funding, relative to the general European framework, with several stages of simplification, in order to facilitate their management and access at national and regional level. Pursuing objectives at EU level is largely compatible with reducing regional disparities, in the sense that, for example, supporting innovation or sustainable development in less developed regions is an important means of achieving this goal. Closer links to the overall EU policy agenda also underline the fact that cohesion policy does not focus exclusively on less developed regions, but supports investment in all regions, with a view to promoting common EU objectives.

In addition to the goal of reducing regional disparities, cohesion policy has come to be more closely aligned with the EU's overall policy agenda.

In order to assess the impact of the effects of the implementation of the projects financed through the Cohesion Policy instruments 2007-2013 at the level of the European Union states, a composite indicator called the Cohesion Policy Impact Measurement Index 2007-2013 (IMIPC) was built. Verification of the objectives taken into account in the construction of this Cohesion Policy Impact Measurement Index 2007-2013 was an analysis of the correlation between it and the Gross Domestic Product, the level of GDP of a country being considered a predictor of the impact of cohesion policy.
\end{abstract}

KEYWORDS: structural funds, cohesion policy, economic development, multivariate analysis, composite indicator

\section{INTRODUCTION}

The general opinion on the need to become a state of the European Union also involved the perception of the benefits that this quality will bring to the citizens, considering at the public level that the European money received will ensure the realization of projects that the country needs to ensure an increased level of quality of life.

Although there are, from the first decades after the establishment of the 3 European communities, funds specially created to generate a balanced development, starting from the premise that the low standard of living leads to potential conflicts, there are still no studies or clear evidence, accepted at the level of experts or at the level of institutions that explicitly link the level of development to the use of funds made available by the EU through its policies. With increased allocations from one programming period to another, European public policy on economic and social cohesion aimed to generate a positive impact, especially at local level, although it could not be individualized and extracted from the general context of all contributing factors. at a certain level of development, at some point.

Member States, according to European Council Regulation no. 1083, adopted in 2006 identified for support regions / areas that can make an important contribution to the achievement of the Lisbon

\footnotetext{
${ }^{*}$ Corresponding author. E-mail address: mihaela.mihai@,csie.ase.ro
} 
objectives, thus generating a double focus and attention from the Member States from the 2 converging perspectives - the objectives of the renewed Lisbon Strategy, as well as the objectives of cohesion policy. In addition, progress evaluation systems have been linked and strengthened as follows:

- The progress made by each Member State in achieving the objectives of the Strategy is set out in the National Reform Programs, annual documents, in which, since 2007, there has been a special section on the role that European cohesion policy has in this regard.

Within the cohesion policy, the progress registered in achieving the objectives of each operational program is reported annually, a tool for fulfilling the objectives of the National Strategic Reference Frameworks. Also, every 3 years, strategic reports were prepared in 2009 and 2012, including information on the contribution of cohesion policy to the Lisbon Strategy. On the basis of these, the Commission may make proposals to adapt the programs to the existing context.

In order to achieve coherence and complementarity of interventions, the Commission has proposed Strategic Guidelines, setting out a way of indicating the types of support from the Funds, taking into account other relevant policies adopted at European level. At Member State level, the National Strategic Reference Framework is the central piece that ensures that FSC assistance is consistent with the National Reform Program and in conjunction with the Strategic Guidelines. Furthermore, the Operational Programs are those containing FSC measures in each Member State, for a period of 7 years, for only one of the three objectives (EC Regulation 1083/2006).

\section{STATE OF THE ART}

Considered one of the main policies at EU level, regional development policy has evolved as the nation-state-region relationship has evolved, strengthening the multi-level governance system being absolutely necessary for a real functioning of regional development policy and creating a real effect of this policy (Wallace, et al, 2010).

Economic convergence leads not only to political implications, but also to in-depth analyses and debates reflected in the literature. Solow's (1956) neoclassical approach is based on the fact that in less developed countries, due to faster economic growth, inequalities tend to decrease. This is contradicted by Myrdal's theory (1957 in Linder, 1961), by the endogenous theories of economic growth enunciated by Romer $(1986,1994)$ and Lucas (1988 in Postoiu, 2015) or by Krugman's new geographical economy (1991) who argue that disparities tend to widen because economic growth is influenced by a cumulative causal effect. Quah (1996), following a global empirical analysis, demonstrated the existence of a sense of income bipolarity by dividing countries into "convergence clubs". Based on the fact that economic disparities arise due to the difference in the implementation of new technologies in developed countries from poorly developed ones, he stressed that while poor states tend to remain underdeveloped and rich states will remain at least at the same level, states at a medium level of development will follow the path to one of these two "clubs". This phenomenon is also explained by the fact that in developed regions, due to high quality factors of production along with new technologies and a modern infrastructure, higher rates of income (accelerator-multiplier mechanism) are generated (Bușega, 2016). Economic disparities tend to diminish in the market economy, which is in line with the neoclassical theory of localization, but in contradiction with the new geographical economy. The latter, through a cumulative circular process that leads to other imbalances of development levels, involves the consolidation of economic concentration in a region (Clipa et al., 2012).

On the other hand, we can say that neoclassical theory lacks two fundamental processes: agglomeration and labour and capital flows. Based on these theories it is possible to study the correlations between the concentration of economic activities as a form of manifestation of economic divergence and the process of economic growth. The new geographical economy allows, through the 'centre-periphery' model introduced by Krugman (1991), the identification of how transport costs and 
the mobility of production factors can lead to changes in the space economy. On the other hand, Țarțavulea (2016) pointed out the globalization process has stimulated the demand for logistics services at a high level of speed and efficiency, which involves the use of modern techniques, tools, technologies and models in supply-delivery chain management. Also, the use of spatial modelling to determine the optimal locations of logistics centres in a predefined economic area presented a model that can be used to design an optimized logistics chain, associated with minimum transport costs (T,arțavulea, et al., 2016). The new theories are based on an equalization of capital per unit of labour. Practically this fact is in contradiction with the neoclassical theories that support the hypothesis according to which the capital moves from the developed regions, and the labour force from the less developed regions. The fact that new theories support the idea of the lack of convergence between regions is also reflected in the literature and empirical studies conducted at European level.

In analysing the dynamics of economic disparities, Puigcerver-Peñalver (2007) estimated the impact of the Structural Funds on the growth rate of 1989 and 2000 in Objective 1 eligible regions, using a hybrid model that partially endogenises the rate of technological progress, highlighted the positive impact that the Structural Funds have had in these regions. Similarly, the impact of European integration on income disparities has been analysed at the level of EU Member States (CrespoCuaresma et al., 2003, in Eckey, 2005). While being an EU Member State has a positive effect on long-term economic growth is a clear result, it has been shown that there is still an asymmetry between Member States at national level. The SURE model is a dynamic model for the analysis of regional disparities in eight Member States of the European Union, proposed by Petrakos et al. (2003). The SURE model uses time series, and the results of the analysis at the level of the eight countries indicate a process of short-term divergence and long-term convergence.

The growing concern about reducing these regional disparities has made EU regional policy financial instruments the fastest growing component of the EU budget. Although the significant contribution of structural and cohesion funds at the regional level is invoked, analyses show that poor states have recovered developmental differences faster than poor regions (Zaman \& Georgescu, 2009), over the last fifteen years, income disparities between EU-15 states have declined, but inequalities between regions in each Member State have increased. EU enlargement has contributed to an even stronger regional gap, with financial instruments alone being ineffective in the absence of adequate regional development policies (Huffschmid, 2005; Horváth, 2009). Studies examining the process of convergence in Central and Eastern Europe (CEE), from a multidimensional perspective, at different regional levels, show that this area of the EU is relatively homogeneous, with disparities within CEE being smaller than in Western Europe, or at the NUTS III level (Topaloglou, 2005), even in the context of the recent economic crisis (Goschin, et al., 2010; Benedek, et al., 2015). Although there are opinions that claim that there has been a "regionalization" of regional policy (Keune, 2001) in Romania how the deficiencies of management and control system of structural and cohesion funds have affected the possibilities of accessing or implementing projects due to external causes local authorities, we can still talk about an indirect regional policy (Nijkamp et al., 1981).

The analysis of regional disparities has gained more and more attention from specialists with the addition of the third dimension of cohesion, along with the economic and social one. Thus, introduced by the Lisbon Treaty, 2009, Article 174 of the Treaty on the Functioning of the EU states that: "In particular, the Union aims to reduce the gaps between the levels of development of different regions and the lagging behind of disadvantaged regions".

The concept of territorial cohesion is a new one, its initial use being correlated with the publication by the European Commission of The Second Report on Economic and Social Cohesion which contains a section on this phenomenon and analyses for the urban and rural environment (Faludi, 2005). Territorial cohesion is also influenced by the traditions and attitudes it generates (Falaudi, 2009) and is also correlated with the developments generated in the area of land use planning marked by the European Space Development Perspective (ESDP). ESDP aims to achieve a polycentric urban development based on a new system of urban-rural relations. At the same time, we want equal access 
to infrastructure and knowledge as well as, of course, prudent management of cultural and natural heritage. As pointed out by Soare (2017), the success and performance of the strategy for economic development based on diversity and regional resources, which is also reflected in tourism, especially in rural tourism. Thus, in a strategy for the development of rural tourism in a region, will take into account the protection and conservation of the tourist environment and implicitly the assessment of natural capital in accordance with its diversity and vulnerability, the objective being to achieve the weight of protected areas European Union (Soare, et al., 2017).

Falaudi (2009) emphasizes that the evolution of territorial policies seeks to solve the social problems faced in the process of achieving cohesion at the level of the European Union and to cover the diversity of economic challenges. Thus, the three Cs are highlighted in the European Commission's report Green Paper on Territorial Cohesion Turning territorial diversity into strength: Concentrating or overcoming density differences, Connecting or overcoming the distance factor and Cooperation or overcoming the division factor (COM (2008) 616 final). However, although urban policies differ widely at national level, and most often in EU Member States they are the implicit result of planning and spatial planning laws in line with sectoral policies, and at European level concerns are also reaffirmed. on the urban agenda and the role of cities (COM (2014) 490 final).

In the states of Central and South-Eastern Europe there is, with the acquisition of EU membership, the challenge of rediscovering the responsible territorial actors and a new territorial management framework to compensate for the forced territorial homogenization during communism (Ancuța \& Brujan, 2008) or to make it possible to replace centralized planning with free market mechanisms (Artelaris, 2010). Overcoming this type of problem can be one of the reasons why European financial support cannot overcome the missing elements (Sapir et al., 2004). The allocation of European financial support under common conditions for Member States after the accession of Romania and Bulgaria has generated debate, with opinions that new Member States may need to meet basic conditions until they become competitive (Wallace et al, 2010). In this area, urban development needed a new paradigm, given that the link between polycentric development and reducing regional disparities is not unanimously supported (Meijers \& Sandberg, 2006), which is much more appropriate for the EU15.

\section{FSC ALLOCATION BY OBJECTIVES 2007-2013}

The Structural and Cohesion Funds, the European Investment Bank and other funds / financial instruments each contribute appropriately to the achievement of the three objectives set for 2007-2013:

- Convergence Objective - priority from the perspective of allocating $81.5 \%$ of funds, which are planned to be spent in the regions covered by this objective; seeks to increase the pace of economic balancing and the level of employment of active human resources in the Member States and regions; making as many and quality investments as possible in everything that involves infrastructure and human capital; increasing the level of innovation and science in society; creating the capacity to adapt to social dynamics and the specificity of the economic environment; protecting and improving the environment; administrative efficiency. Financial allocations from the ERDF, the ESF and the CF have been set for this purpose.

- The Regional Competitiveness and Employment Objective aims to strengthen the competitiveness, the capacity of regions to attract investors and a workforce for which there will also be jobs by anticipating change; more and better investments in human capital; promoting science and new discoveries in society; entrepreneurship; protecting and reducing environmental damage; better access in terms of all types of infrastructure and opportunities, for the adaptability of workers and enterprises; supporting the inclusive nature of labour markets. The financial allocations come from the ERDF, the ESF.

- The European Territorial Cooperation Objective purpose to strengthen the modalities of 
cooperation at national borders through: joint projects developed at local and regional level; stronger cooperation between states; measures leading to integrated territorial development linked to Community priorities; strengthening interregional cooperation and collaboration between similar territorial-administrative units, especially in order to disseminate examples of good practice and avoid errors.

347 billion euros were made available for the FSC, compared to 235 billion euros for the previous period 2000-2006. In order to receive financial assistance, Member States submitted NRCs and operational programs, and following negotiations between the European Commission and Member States, 27 National Strategic Reference Frameworks and 455 operational programs were adopted.

At the level of the European Union, the regions benefited from different levels of financial allocation, but subsumed the interventions / measures to priorities assumed by all Member States. Thus, the Convergence objective targets within the EU-27, 84 regions from 17 states, totalling 154 million inhabitants. In addition, there are - in a phase of phasing out - a number of 16 regions with 16.4 million inhabitants and a level of GDP above the threshold that differentiates between the types of objectives, due to the effect generated by differences in development. at the beginning of the period, until the end, statistically reflected after EU enlargement. The amount available under the Convergence Objective is EUR 282.8 billion, representing $81.5 \%$ of the total, distributed as follows: allocations to regions - EUR 199.3 billion; EUR 13.9 billion for regions whose aid is being phased out and EUR 69.6 billion for the Cohesion Fund, the latter being applied in 15 Member States. The beneficiaries are a total of 168 regions that are part of 19 states with 314 million inhabitants. Within them, 13 regions with a population of 19 million are areas where support is gradually being introduced, exceeding the limits and accessing a superior goal than to Objective 1. EUR 54.9 billion (less than $16 \%$ of the total) - of which EUR 11.4 billion is for regions where support is gradually being introduced.

Objective 3 is intended for the population living in cross-border areas, i.e. 181.7 million inhabitants (37.5\% of the total EU population). The 13 areas of cooperation between states are also added. The allocated budget of EUR 8.7 billion (2.5\% of the total) is divided as follows: border cooperation receives EUR 6.44 billion, transnational cooperation receives EUR 1.83 billion, and cooperation between regions and interregional networks receives EUR 445 million. The method of calculating the allowances is set out in the EU regulations governing cohesion policy instruments. It distinguishes between the three objectives, and the final share depends mainly on the relative regional and national prosperity, the number of inhabitants and the unemployment rate, with funding below around $4 \%$ of GDP, per Member State.

More funds are allocated to environmental initiatives for sustainability than ever before. The environment can be useful for economic impetus, by encouraging innovative and clean technologies, by promoting an efficient use of energy, by developing ecotourism or by natural habitats that increase the attractiveness of areas. Ensuring sustainable development and a high level of environmental protection is necessary in all European Union policies. The legal bases and guidelines of regional policy also provide for the integration of economic, social and environmental objectives, so that regional policy can contribute to the sustainability of the European Union by promoting green technologies; of initiatives related to transport, energy and quality water, air and soil infrastructure. For this reason, Member States have a responsibility to carry out environmental impact assessments and to consult with environmental authorities and the public when implementing cohesion policy programs.

As a consequence, the total amount of FSC allocated to environmental programs is 2 times higher than in the previous period, reaching around EUR 100 billion. 50\% of this will be dedicated to infrastructure investments related to water and waste treatment, cleaning up contaminated areas, reducing pollution, supporting nature protection and preventing risks. The rest of the amount will be dedicated to relevant investments as an effect on the environment in areas such as transport and energy systems, eco-innovation, environmental management for enterprises, urban and rural regeneration 
and ecotourism. Thus, more than EUR 7 billion will be used to support energy efficiency and renewable energies. At the same time, the Cohesion Fund is the major source of funding for environmental infrastructure projects, especially in the fields of energy efficiency, renewable energy, rail transport and intermodal or public transport systems. It provides funding for investment-intensive projects and helps these countries meet European Union environmental standards.

Regions across Europe will also have to deal with the effects of adverse climate change, as well as new challenges related to energy supply and energy efficiency. These will vary by region, with $7 \%$ of EU residents living in flood-prone areas and around 9\% in areas where there is no rainfall for more than 4 months a year. The combined impact of climate change will raise serious issues of quality of life, tourism and agriculture in some European areas, with cohesion policy being an important factor in supporting efforts to adapt to future climate change and minimizing the negative impact at regional level. It can support eco-innovation, environmental protection measures and non-polluting businesses and can create favourable situations for businesses in those areas.

New regional policy programs provide more support than ever before for the development of renewable and alternative energy sources, which means that there are opportunities for European businesses to benefit from them. The development of technologies, such as wind, solar and biomass, can give the EU an advantage and strengthen its competitive position. Europe's growing dependence on energy imports and the continuing increase in congestion affecting road and air transport are reducing the competitiveness of European industry. Therefore, renewable energy applications and networks, cleaner modes of transport and green technologies are key priorities for modernizing production and reducing emissions. In the field of transport, the rebalancing of funding between road, air and rail transport, inland waterways and maritime transport should take into account the different situations existing in the EU Member States.

\section{COHESION POLICY IMPACT MEASUREMENT INDEX 2007-2013 FOR EU STATES (IMIPC)}

A composite indicator called the Cohesion Policy Impact Index 2007-2013 (IMIPC) has been built to analyse the impact of cohesion policy at EU level. The developed indicator takes into account a number of 12 variables that represent, on the one hand, socio-economic development indicators for EU countries in 2016, (real GDP index / loc., EU28 = 100; unemployment rate; participation rate in education and training (NEET), and on the other hand the outcome indicators of cohesion policy in the period 2007-2013 (Annex 1. Table 2).

The access of funds for cohesion policy in the period 2007-2013 was differentiated at the level of EU Member States according to the eligibility of regional criteria, as a result we do not find values of variables for all EU member states. For this reason, in order to be able to develop the analysis, explicit modelling was needed using the imputation of data by the unconditioned average. In order to mitigate the variability of the data, the imputation was made, differentiated, according to the level of development of the states, a level that was the basis of the eligibility for a certain objective of the cohesion policy. Although the eligibility of EU regions and states for one purpose or another has been determined by GDP / place. (prior to cohesion policy 2007-2013), for the determination of groups of similar countries as socio-economic development, in order to impute the data, the Social Progress Index (SPI) calculated for 2016 was used (https://ec.europa.eu/regional_policy/en/information/maps/social progress).

Please note that Malta is not included in the analysis carried out, as no data were identified for the outcome indicators of cohesion policy in the period 2007-2013. Based on the indicators used in the construction of SPI, using Cluster Analysis, the countries were grouped into three clusters as shown in the dendrogram (Figure 1). 


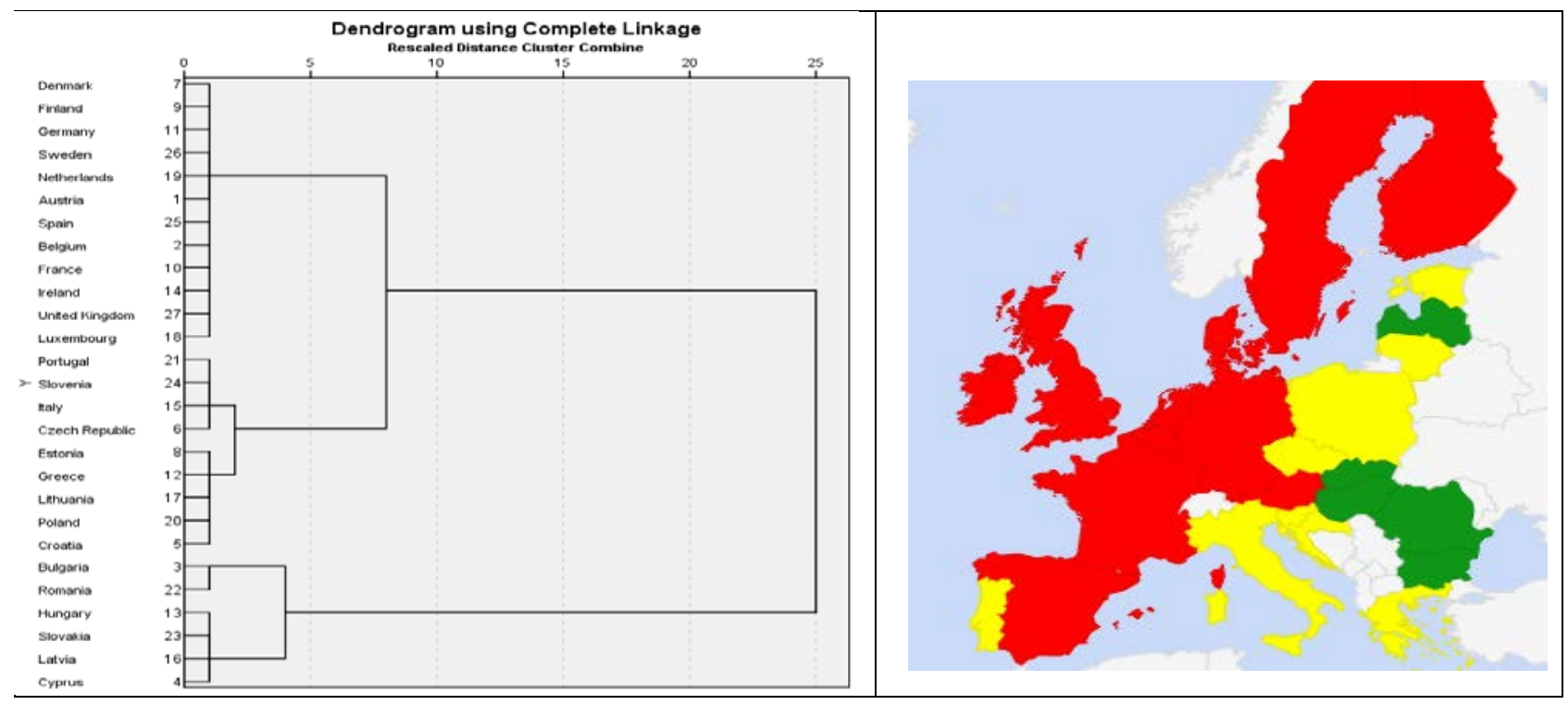

Figure 1. The EU states that make up the three clusters

Source: Authors' own research

The construction of IMIPC at the level of EU states has as a starting point the Principal component analysis (PCA). The use of this analysis aims to reduce the dimensionality of the data space by establishing components that synthesize the influence of the variables considered, but also to preserve as much as possible the total variation of the initial data set. In addition to the new components obtained, the mathematical relationships that establish the connection between the initial variables and them are determined, and by using the factor rotation method, one of the best solutions generated by factor analysis is obtained, from an infinity of existing solutions.

The indicators used in the PCA have been standardized to ensure comparability of data, and the results obtained using XLSTAT Addinsoft (2019). XLSTAT statistical and data analysis solution. Boston, USA. https://www.xlstat.com) are as follows:

Table 1. ACP - Factors with super unit eigenvalues

\begin{tabular}{|c|c|c|c|c|c|c|c|c|c|c|c|c|}
\hline & F1 & F2 & F3 & $\mathrm{F} 4$ & F5 & & & & & & & \\
\hline Eigenvalue & 4.457 & 3.600 & 2.343 & 1.627 & 1.125 & & & & & & & \\
\hline Variability (\%) & 26.217 & 21.178 & 13.780 & 9.572 & 6.617 & & & & & & & \\
\hline Cumulative $\%$ & 26.217 & 47.395 & 61.175 & 70.747 & 77.364 & & & & & & & \\
\hline & F6 & F7 & F8 & F9 & F10 & F11 & F12 & F13 & F14 & F15 & F16 & F17 \\
\hline Eigenvalue & 0.840 & 0.756 & 0.618 & 0.432 & 0.348 & 0.292 & 0.242 & 0.127 & 0.089 & 0.062 & 0.034 & 0.008 \\
\hline Variability (\%) & 4.940 & 4.449 & 3.636 & 2.543 & 2.048 & 1.715 & 1.422 & 0.748 & 0.523 & 0.364 & 0.200 & 0.049 \\
\hline Cumulative \% & 82.304 & 86.753 & 90.389 & 92.931 & 94.979 & 96.694 & 98.116 & 98.864 & 99.387 & 99.751 & 99.951 & 100.000 \\
\hline
\end{tabular}

Table 1 contains the eigenvalues of the model, values that reflect the projection quality of the initial Ndimensional data set $(\mathrm{N}=17)$ at a smaller number of dimensions. It can be seen that the first eigenvalue is equal to 4,457 and summarizes $26 \%$ of the total variability.

Each eigenvalue corresponds to a factor and each factor a dimension. Although it is ideal that the first two or three eigenvalues correspond to a high percentage of variation, so that the representations based on the first two or three factors constitute a good quality projection of the initial multidimensional set, in the analysis we notice that the first five eigenvalues express about $77 \%$ of the initial variability of the data.

The correlation circle (Annex 1. Figure 6) (on axes F1 and F2) shows a projection of the initial variables in the factor space. For two variables located at a distance from the centre we can have the following interpretations:

- their proximity shows a significant direct correlation ( $r$ tends to 1$)$; 
- if they are orthogonal then there is no connection between them ( $r$ is about 0$)$;

- if they are located on opposite sides relative to the centre of the circle, then they are significantly negatively correlated ( $r$ close to -1$)$.

There are situations when certain information may overlap and the interpretation may be misleading. For example, we may interpret a strong correlation between variables V9 - Number of cooperation projects between enterprises and research institutions and V10 - Number of start-ups supported, although in fact this is low. This can also be confirmed by examining the correlation matrix (Annex 1. Table 3). In the elaboration of the correlation matrix a nonparametric correlation coefficient (Spearman) was used, this being adequate to this analysis when we run variables with different distributions.

The correlation circle is also useful in interpreting the significance of the axes, in the analysis performed the horizontal axis being correlated with the variables related to infrastructure, and the vertical one with the jobs created following the application of cohesion policies in the period 2007-2013. This fact is also confirmed by the square of the cosines of the variables (Annex 1. Table 4), the higher its value, the stronger the connection between the variable and the corresponding axis. At the same time, we note that the variables V16 and V17, which represent the Unemployment Rate (\%), respectively people aged 1624 were Not in Education, Employment or Training (NEET), annual averages, would be better highlighted on an F3 / F4 representation.

The observation contribution diagram (Annex 1. Figure 7) allows us to analyse the observations on a two-dimensional map (F1 / F2) and identify trends: we can identify the uniqueness of the application of cohesion policies in 2007-2013 in Poland and the UK, as well as similarities between the effects their application in the United Kingdom and Spain. Varimax rotation (Annex 1. Table 5) facilitates the interpretation of results by maximizing the variance of the square load of factors on the column.

The analysis of the load of factors after the rotation of Varimax (Annex 1. Table 6) shows that the first factor is strongly correlated with the variables: V12, V13, V14 and V15, while the second factor, obtained after rotation, is more loaded for the variables V4, V5, V6, V9, V10 and V11. The solution determined from the analysis indicates five factors that explain approximately $77 \%$ of the total variability of the model. (Annex 1. Table 7). The factors identified following the analysis performed are:

- Factor 1 (Infrastructure) consists of the variables: New roads built $(\mathrm{km})$, New roads TEN built $(\mathrm{km})$, Rehabilitated roads $(\mathrm{km})$ and Additional renewable energy production capacity;

- Factor 2 (Jobs) includes the variables: Total number of newly created jobs, Number of jobs created in research, Number of jobs created in SMEs (full-time equivalent). Number of enterprises that received support, Number of cooperation projects between enterprises and research institutions and Number of start-ups supported.

- Factor 3 includes the variables: Unemployment rate, NEET and Participation rate in education and training;

- Factor 4 includes the variables: Number of jobs created in tourism, Number of students who received funding and Number of enterprises that received support;

- Factor 5 (Economic Development) summarizes the variables: Real GDP / inhabitant index and EU funds absorption rate 2007-2013;

The contribution of the variables to the formation of the factors (Annex 1. Table 9), summarizes the contribution of the variables to the formation of the five factors retained in the model, led to the determination (as arithmetic mean) of the coefficients associated with the variables used in the IMIPC calculation.

To obtain the IMIPC the determined coefficients were applied to the ranks associated with the values of the variables to improve the incompatibility of the data (Annex 1. Table 9).

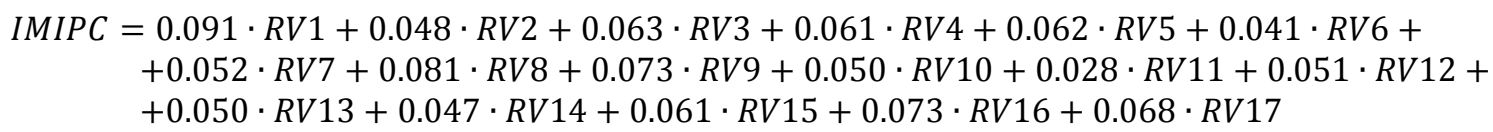


The purpose of the Cohesion Policy Impact Measurement Index 2007-2013 is to highlight the differences and similarities between EU countries in terms of the economic and social effects of accessing ERDF, ESF and Cohesion Fund funding.

\begin{tabular}{|l|r|}
\hline Country & IMIPC value \\
\hline Austria & 13.34 \\
\hline Belgium & 15.53 \\
\hline Bulgaria & 17.30 \\
\hline Croatia & 15.38 \\
\hline Cyprus & 19.52 \\
\hline Czech Republic & 12.22 \\
\hline Denmark & 10.28 \\
\hline Estonia & 16.26 \\
\hline Finland & 11.88 \\
\hline France & 14.55 \\
\hline Germany & 9.94 \\
\hline Greece & 16.69 \\
\hline Hungary & 10.36 \\
\hline Ireland & 14.14 \\
\hline Italy & 14.02 \\
\hline Latvia & 18.55 \\
\hline Lithuania & 14.15 \\
\hline Luxembourg & 12.69 \\
\hline Netherlands & 10.12 \\
\hline Poland & 8.75 \\
\hline Portugal & 15.77 \\
\hline Romania & 16.56 \\
\hline Slovakia & 18.59 \\
\hline Slovenia & 16.24 \\
\hline Spain & 11.83 \\
\hline Sweden & 11.66 \\
\hline United Kingdom & 11.65 \\
\hline
\end{tabular}

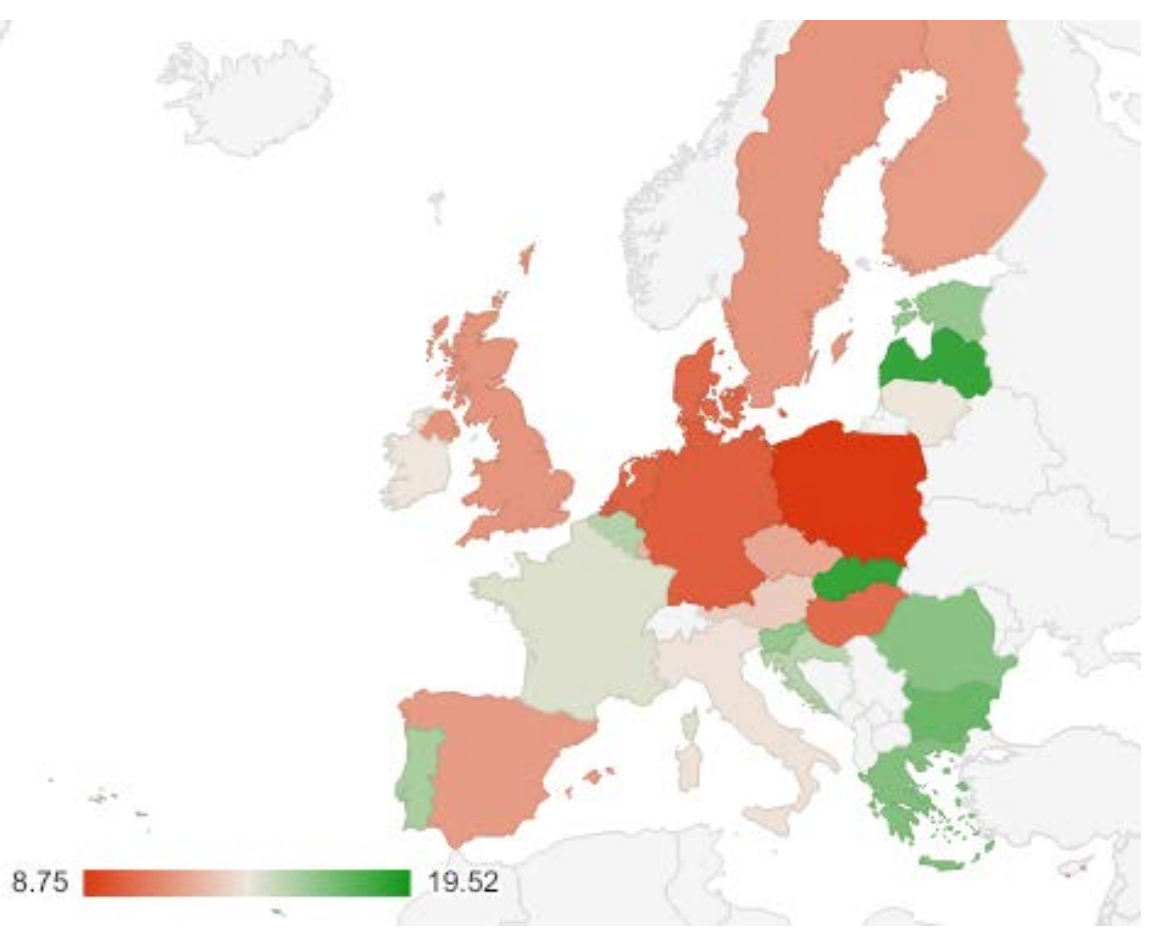

Figure 2. EU countries according to IMIPC values

Source: Authors own research

The cluster analysis performed, starting from the values of this index, divides the EU states into three classes, with a different composition from the one initially performed based on the Social Progress Index.

The constructed index evaluates the impact of the effects of the implementation of the projects financed through the Cohesion Policy instruments 2007-2013 at the level of the European Union states. The values obtained for the developed index are in line with the three objectives of Cohesion Policy. Thus, a high value of the index shows a significant impact of the absorption of funds on the economic and social development of the respective state, while its low values indicate a lower impact. The most developed EU countries have low IMIPC values, with high levels of the index for socio-economically less developed countries.

\subsection{Validation of the Cohesion Policy Impact Index 2007-2013 for EU countries (IMIPC)}

In order to verify the objectives taken into account in the construction of this index, an analysis was made on the correlation between IMIPC and GDP, the level of GDP of a country being considered a predictor for the impact of cohesion policy.

Based on the IMIPC and GDP values for 2016 (million euros), the non-parametric correlation analysis used shows an inverse, significant link for a significance level of 5\% (Annex 2. Table 11).

The distribution graphs for the two variables show an approximately normal distribution, in the case of IMIPC, and a deeply asymmetric distribution to the right for the GDP variable (Annex 2. Figure 9). This situation recommends the use of non-parametric methods of link analysis, the correlogram not being conclusive.

For the analysis of the dependence between IMIPC and GDP, using statistical regression it was necessary to logarithm the values of the GDP variable to correct the form of distribution (Annex 2. 
Figure 10). The normality tests, applied after logarithm, indicate that the distribution of the $\operatorname{lgPIB}$ variable is normal for a significance level of 5\% (Annex 2. Figure 11).

The correlogram between the two variables shows the existence of an inverse and approximately linear link, and the calculated Pearson correlation coefficient, after logarithm of the GDP variable, is about -0.61 , which shows an inverse correlation, of medium intensity, statistically significant for a significance level of $5 \%(p-$ value $=0.001)$.

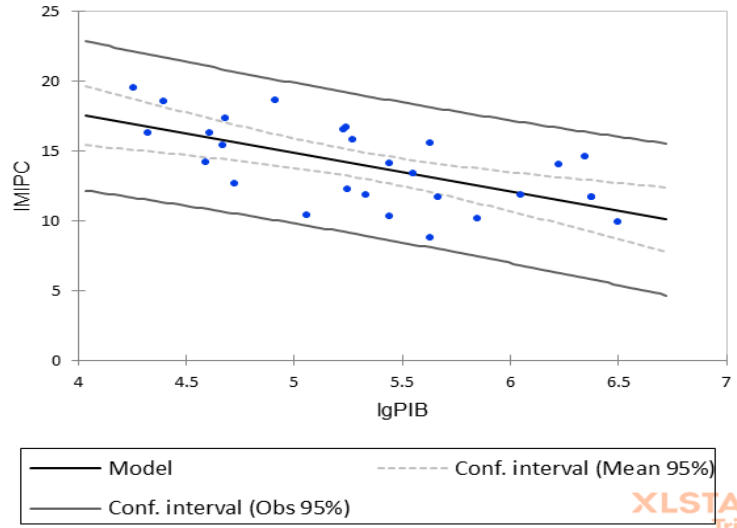

Figure 3. Regression IMIPC by $\operatorname{lgPIB}\left(\mathrm{R}^{2}=\mathbf{0 . 3 7 1}\right)$ Source: Authors' own research

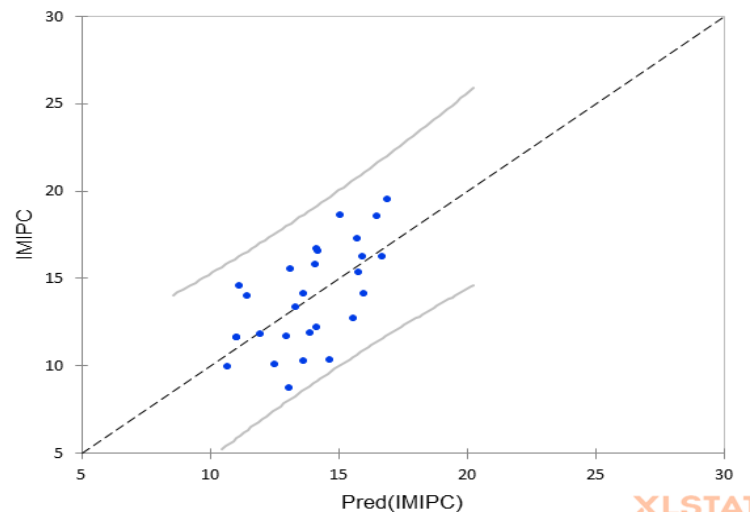

Figure 4. Pred (IMPC) / IMIPC

Source: Authors' own research

The regression model that analyses the dependence between IMIPC and $\operatorname{lgPIB}$ is valid for a significance level of 5\%, the coefficients are statistically significant, for the same significance level, the hypotheses of a regression model regarding the residual variable being verified both by specific tests and graphically (Appendix 2. Figure 12).

The inverse dependence between the two variables shows that the impact of accessing European funds diminishes as an EU Member State makes economic and social progress.

\section{CONCLUSIONS}

The diversity of administrative-territorial structures from the perspective of statistically available data, but also of administrative competences within multilevel governance can make it difficult to compare the evolution at local, regional or national level of the economic and social situation under the intervention of European cohesion. The extent of the construction of the European Union under the succession of accession stages was reflected in social, economic and territorial terms for example after 1995, in the case of Portugal, Ireland, Spain or Greece or after 2007, when Romania and Bulgaria joined the EU group. However, 2017 is the year in which the European Commission, in the Seventh Report on Economic and Social Cohesion, states that Eastern European countries such as Poland, Hungary, Bulgaria, Romania will need at least another 15 years, for the average GDP / place to reach 75\% of the average GDP / place in Europe, in the context of an economic development obtained after 2007, undisputed, but justified by the low economic and social level since accession, as well as by obtaining a development process around the big cities or capitals.

In the period 2007-2013, the significance of cohesion policy increased, the 3 objectives set at Union level being met with the help of the budget allocated for this type of policy. The more than EUR 340 billion was mostly used (over $80 \%$ ) for projects in convergent regions, sometimes supplementing the national budget for public investment, especially during the crisis.

The Structural and Cohesion Funds have evolved with the need for states for funding, relative to the general European framework, with several stages of simplification, in order to facilitate their management and access at national and regional level. Since 2007, employment by creating an environment for employers to adapt, as well as the development of the urban environment, metropolitan 
areas or growth poles have been boosted since the adoption of EC regulations, relying on the dissemination of development.

Although substantial funding has been generous, regional disparities have persisted, with various theories regarding the correlation of cohesion policy intervention with the reduction of development disparities, sometimes showing that inequalities have widened, especially if the state did not have a policy. consolidating or enhancing the effects generated by European-funded projects. Thus, it was appreciated in some cases that rich states maintained their high level of development, while the least developed remained the same, complicated by the existence of centre-periphery dynamics that generated mobility in different directions of capital and labour.

The analysis of regional disparities involved the use of indices, indicators or methods from the most used, respectively GDP / place that gives the financial allocation for cohesion policy, to the Gini coefficient, the Herfindahl - Hirschman index, or the Lorenz-Gini curve concentration or localization coefficients or sigma convergence. The EU Regional Social Progress Index (IPS-EU) at European level (2016) is clear evidence of the growing interest in the social dimension of cohesion. The Cohesion Policy Impact Measurement Index 2007-2013 IMIPC highlights the common or different elements that exist between EU states on the social and economic dimension of FSC use.

The assessment of the impact of the effects of the implementation of the projects financed through the Cohesion Policy instruments 2007-2013 at the level of the European Union states with the help of IMIPC is in line with the three objectives of the Cohesion Policy. Thus, the most developed EU countries have low IMIPC values, with high levels of the index being recorded for less developed countries from a socio-economic point of view. The high values obtained for the developed index highlight the significant impact of the absorption of funds on the economic and social development of the respective state.

\section{ACKNOWLEDGMENT}

This work was cofinanced from the European Social Fund through Operational Programme Human Capital 2014-2020, project number POCU/380/6/13/125015 "Development of entrepreneurial skills for doctoral students and postdoctoral researchers in the field of economic sciences"

\section{REFERENCES}

Ancuţa, C., \& Brujan, L. (2008). Cohesion and Disparities. Regional and Local Development in Central and South-Eastern Europe between Potentials, Policies and Practices. Geogaphica Timisiensis, 17, 1-2.

Artelaris, P., Kallioras, D., \& Petrakos, G. (2010). Regional inequalities and convergence clubs in the European Union new member-states. Eastern Journal of European Studies, 1(1), 113.

Antonescu, D., (2013). How Will Be The Future Of Regional Policy In European Union? Revista Economică, 65(5), 7-17.

Benedek, J., Cristea, M., \& Szendi, D. (2015). Catching up or falling behind? Economic convergence and regional development trajectories in Romania. Romanian Review of Regional Studies, 11(1).

Bușega, I. (2016). The impact of economic crisis on regional disparities in Romania. Testing Williamson's hypotesis in the context of economic and financial turmoil. Romanian Review of Regional Studies, 12(1).

Clipa, R. I., Pohoaţă, I., \& Clipa, F. (2012). The new economic geography and regional policy in Romania. Theoretical \& Applied Economics, 19(8).

Eckey, H. F., \& Türck, M. (2005). Convergence of EU-regions: A literature report (No. 80). Volkswirtschaftliche Diskussionsbeiträge. 
Faludi, A. (2005). Territorial cohesion: an unidentified political objective: introduction to the special issue. Town Planning Review, 76(1), 1-13.

Faludi, A. K. F. (2009). Territorial Cohesion under the Looking Glass: Synthesis paper about the history of the concept and policy background to territorial cohesion, European Commission, Regional Policy, Inforegio.

Goschin, Z., Constantin, D. L., \& Danciu, A. R. (2010). A regional perspective on the impact of the current economic crisis in Romania. Romanian Economic and Business Review, 5(3), 204.

Guvernul României (2009) Raportul Strategic Național privind implementarea Fondurilor Structurale și de Coeziune http://www.fonduri-ue.ro/res/filepicker_users/cd25a597fd62/Documente_Suport/Evaluari/0_EVALUARI_CSNR/4a_Raport_Stratg_Nat_Impl_IS_(RO). pdf [Accessed 9 October 2020]

Horváth, G. (2009). Cohesion deficiencies in Eastern and Central Europe-Inequalities of regional research area. Discussion Papers, (72), 5-40.

Huffschmid, J. (2005). Economic policy for a social Europe. London: Palgrave Macmillan.

Keune, M. Regions, regional institutions and regional development. International Labour Office, 2001, p.41.

Krugman, P. (1991). Increasing returns and economic geography. Journal of political economy, 99(3), 483-499.

Linder, S. B. (1961). An essay on trade and transformation (pp. 82-109). Stockholm: Almqvist \& Wiksell.

Meijers, E., \& Sandberg, K. (2006, August). Polycentric development to combat regional disparities? The relation between polycentricity and regional disparities in European countries. In Proceedings from the 46th Congress of the European Regional Science Association, Volos, August 30th-September 3rd.

Nijkamp, P., Hans, G., Sigar, E., A multidimensional analysis of regional infrastructure and economic development. Free University, Department of Economics, 1981, p. 6

Petrakos, G., Rodríguez-Pose, A., \& Rovolis, A. (2003). Growth, integration and regional inequality in Europe.

Postoiu, C., \& Busega, I. (2015). Inter-regional disparities in the European union. Romanian Review of Regional Studies, 11(1), 3.

Puigcerver-Peñalver, M. C. (2007). The impact of structural funds policy on European regions growth. A theoretical and empirical approach. The European Journal of Comparative Economics, 4(2), 179-208.

Quah, D. T. (1996). Empirics for economic growth and convergence. European economic review, 40(6), 1353-1375.

Regulamentul CE 1083/2006, Titlul III Programare, Capitol I Prevederi generale privind Fondurile Structurale și de Coeziune,

Romer, P. M. (1986). Increasing returns and long-run growth. Journal of political economy, 94(5), 1002-1037.

Romer, P. M. (1994). The origins of endogenous growth. Journal of Economic perspectives, 8(1), 3-22.

Sapir, A., Aghion, P., Bertola, G., Hellwig, M., Pisani-Ferry, J., Rosati, D., ... \& Smith, P. M. (2004) An Agenda for a Growing Europe: The Sapir Report: The Sapir Report. Oxford University Press.

Soare, I., Dobrea, N. C. R. C., \& Nastase, M. (2017). The Rural Tourist Entrepreneurship-New Opportunities of Capitalizing the Rural Tourist Potential in the Context of Durable Development. European Journal of Sustainable Development, 6(3), 231-231.

Solow, R. M. (1956). A contribution to the theory of economic growth. The quarterly journal of economics, 70(1), 65-94.

Topaloglou, L., Kallioras, D., Manetos, P., \& Petrakos, G. (2005). A border regions typology in the enlarged European Union. Journal of Borderlands Studies, 20(2), 67-89. 
Țarțavulea (Dieaconescu), R.I., Belu, M.G., Paraschiv, D.M. and Popa, I., 2016. Spatial Model for Determining the Optimum Placement of Logistics Centers in a Predefined Economic Area.

Amfiteatru Economic, 18(43), pp. 707-725

Wallace, H., Pollack, M. A., \& Young, A. R. (Eds.). (2010). Policy-making in the European Union.

Oxford university press.

Zaman, Gh., Georgescu, G., Structural Fund Absorption: A New Challenge for Romania?. Romanian journal of economic forecasting 1.2009 (2009): 136-154, p.141.

\section{Annex 1}

Table 2. Analysis indicators

\begin{tabular}{ll} 
Variable Code & \multicolumn{1}{c}{ Variable Name } \\
\hline V1 & Real GDP / capita index, (EU28 $=100)$ \\
V2 & Participation rate in education and training (\% of the population aged 25-64 participating in formal and non-formal education in \\
V3 & Absorption rate of EU states EU funds 2007-2013 \\
V4 & Total number of newly created jobs \\
V5 & Number of jobs created in research \\
V6 & Number of jobs created in SMEs (full-time equivalent) \\
V7 & Number of jobs created in tourism \\
V8 & Number of students who received funding \\
V9 & Number of enterprises that received support \\
V10 & Number of cooperation projects between enterprises and research institutions \\
V11 & Number of start-ups supported \\
V12 & Newly built roads (km) \\
V13 & New TEN roads built (km) \\
V14 & Rehabilitated roads (km) \\
V15 & Additional renewable energy production capacity \\
V16 & Unemployment rate $(\%)$ \\
V17 & Young people aged between 15 and 24 are not employed, nor in education and training (NEET), annual averages \\
\hline
\end{tabular}

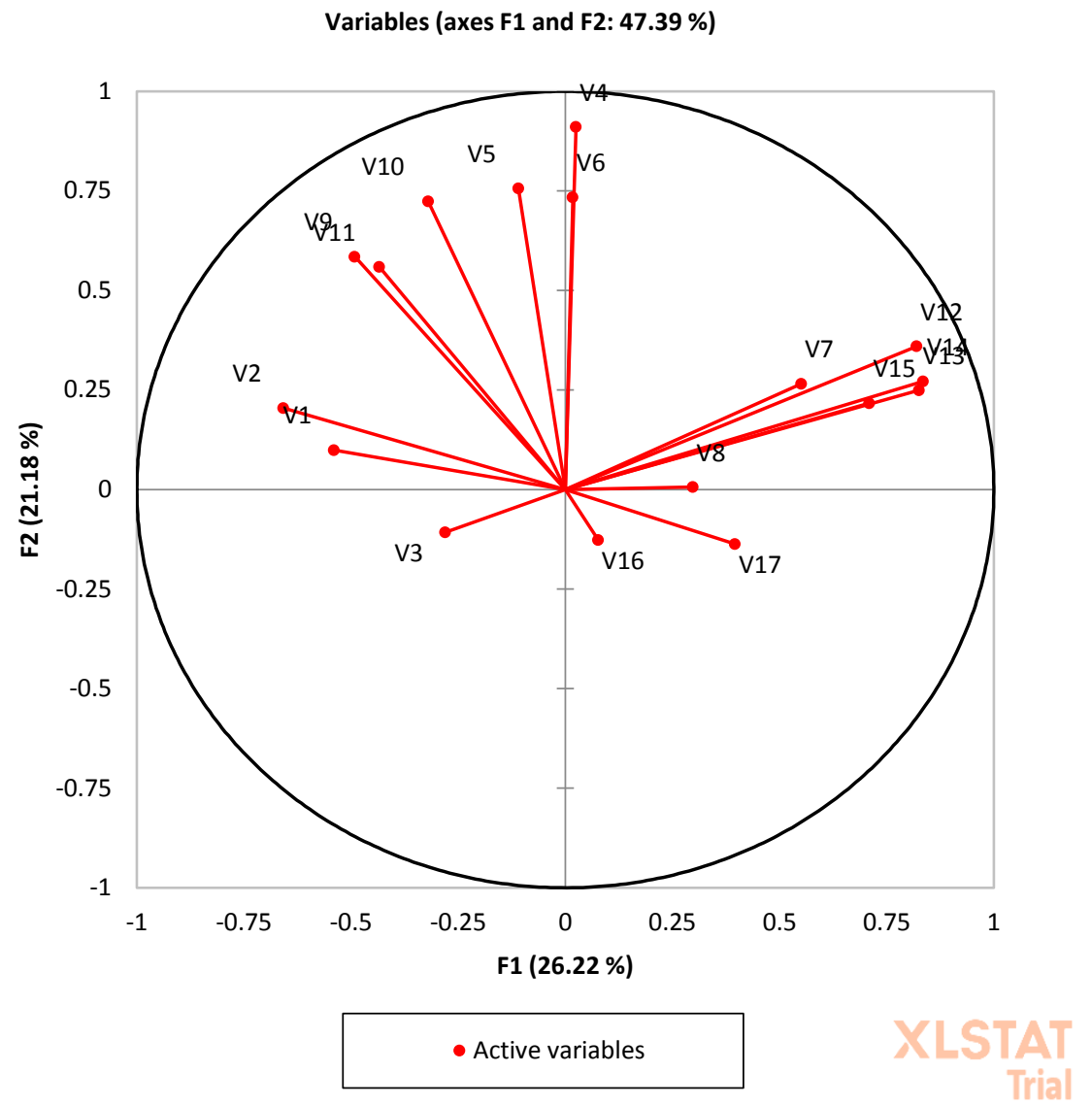

Figure 5. Correlation circle

Source: Authors' own research 
Table 3. ACP - Correlation matrix (Spearman)

\begin{tabular}{|c|c|c|c|c|c|c|c|c|c|c|c|c|c|c|c|c|c|}
\hline Var. & V1 & V2 & V3 & V4 & V5 & V6 & V7 & V8 & V9 & V10 & V11 & V12 & V13 & V14 & V15 & V16 & V17 \\
\hline V1 & 1.00 & 0.69 & 0.16 & 0.11 & 0.20 & 0.08 & -0.26 & -0.46 & 0.70 & 0.32 & 0.33 & -0.32 & -0.46 & -0.54 & 0.00 & -0.24 & -0.60 \\
\hline V2 & 0.69 & 1.00 & 0.20 & 0.14 & 0.28 & 0.11 & -0.05 & -0.31 & 0.35 & 0.28 & 0.21 & -0.38 & -0.47 & -0.44 & -0.21 & -0.34 & -0.54 \\
\hline V3 & 0.16 & 0.20 & 1.00 & -0.44 & -0.35 & -0.09 & -0.44 & -0.04 & -0.04 & -0.09 & 0.03 & -0.29 & -0.20 & -0.27 & -0.43 & 0.14 & -0.26 \\
\hline V4 & 0.11 & 0.14 & -0.44 & 1.00 & 0.82 & 0.47 & 0.18 & -0.17 & 0.39 & 0.66 & 0.46 & 0.28 & 0.16 & 0.02 & 0.37 & -0.33 & -0.04 \\
\hline V5 & 0.20 & 0.28 & -0.35 & 0.82 & 1.00 & 0.40 & 0.09 & -0.22 & 0.34 & 0.74 & 0.35 & 0.08 & -0.04 & -0.21 & 0.13 & -0.28 & -0.10 \\
\hline V6 & 0.08 & 0.11 & -0.09 & 0.47 & 0.40 & 1.00 & 0.09 & 0.01 & 0.29 & 0.28 & 0.46 & 0.33 & 0.19 & 0.19 & -0.07 & -0.36 & -0.20 \\
\hline V7 & -0.26 & -0.05 & -0.44 & 0.18 & 0.09 & 0.09 & 1.00 & 0.18 & -0.31 & 0.06 & -0.02 & 0.04 & 0.12 & 0.06 & 0.13 & -0.23 & 0.15 \\
\hline V8 & -0.46 & -0.31 & -0.04 & -0.17 & -0.22 & 0.01 & 0.18 & 1.00 & -0.31 & -0.20 & -0.09 & 0.17 & 0.00 & 0.31 & 0.01 & 0.43 & 0.37 \\
\hline V9 & 0.70 & 0.35 & -0.04 & 0.39 & 0.34 & 0.29 & -0.31 & -0.31 & 1.00 & 0.36 & 0.56 & 0.01 & -0.16 & -0.14 & 0.27 & -0.14 & -0.37 \\
\hline V10 & 0.32 & 0.28 & -0.09 & 0.66 & 0.74 & 0.28 & 0.06 & -0.20 & 0.36 & 1.00 & 0.27 & -0.17 & -0.20 & -0.35 & -0.03 & -0.19 & -0.04 \\
\hline V11 & 0.33 & 0.21 & 0.03 & 0.46 & 0.35 & 0.46 & -0.02 & -0.09 & 0.56 & 0.27 & 1.00 & -0.06 & -0.13 & -0.12 & 0.09 & 0.03 & -0.17 \\
\hline V12 & -0.32 & -0.38 & -0.29 & 0.28 & 0.08 & 0.33 & 0.04 & 0.17 & 0.01 & -0.17 & -0.06 & 1.00 & 0.81 & 0.76 & 0.42 & -0.14 & 0.06 \\
\hline V13 & -0.46 & -0.47 & -0.20 & 0.16 & -0.04 & 0.19 & 0.12 & 0.00 & -0.16 & -0.20 & -0.13 & 0.81 & 1.00 & 0.63 & 0.40 & -0.17 & 0.02 \\
\hline V14 & -0.54 & -0.44 & -0.27 & 0.02 & -0.21 & 0.19 & 0.06 & 0.31 & -0.14 & -0.35 & -0.12 & 0.76 & 0.63 & 1.00 & 0.37 & 0.04 & 0.17 \\
\hline V15 & 0.00 & -0.21 & -0.43 & 0.37 & 0.13 & -0.07 & 0.13 & 0.01 & 0.27 & -0.03 & 0.09 & 0.42 & 0.40 & 0.37 & 1.00 & -0.04 & 0.01 \\
\hline V16 & -0.24 & -0.34 & 0.14 & -0.33 & -0.28 & -0.36 & -0.23 & 0.43 & -0.14 & -0.19 & 0.03 & -0.14 & -0.17 & 0.04 & -0.04 & 1.00 & 0.57 \\
\hline V17 & -0.60 & -0.54 & -0.26 & -0.04 & -0.10 & -0.20 & 0.15 & 0.37 & -0.37 & -0.04 & -0.17 & 0.06 & 0.02 & 0.17 & 0.01 & 0.57 & 1.00 \\
\hline
\end{tabular}

Table 4. ACP - The square of the cosines of the variables

\begin{tabular}{|c|c|c|c|c|c|c|c|c|c|c|c|c|c|c|c|c|c|}
\hline & F1 & F2 & F3 & $\mathrm{F} 4$ & F5 & F6 & F7 & F8 & F9 & F10 & F11 & F12 & F13 & F14 & F15 & F16 & F17 \\
\hline V3 & 0.08 & 0.01 & 0.17 & 0.07 & 0.20 & 0.00 & 0.44 & 0.00 & 0.01 & 0.02 & 0.00 & 0.00 & 0.00 & 0.00 & 0.00 & 0.00 & 0.00 \\
\hline V5 & 0.01 & 0.57 & 0.00 & 0.14 & 0.08 & 0.00 & 0.00 & 0.14 & 0.00 & 0.01 & 0.02 & 0.00 & 0.01 & 0.01 & 0.00 & 0.00 & 0.00 \\
\hline V6 & .00 & .54 & 0.01 & 0.09 & 0.00 & 0.21 & 01 & & & & .05 & 0.00 & 0.00 & & 0.01 & 0.00 & 0.00 \\
\hline V7 & 0.30 & 0.07 & 0.03 & 0.26 & 0.00 & 0.11 & 0.01 & 0.15 & 0.02 & 0.03 & 0.01 & 0.00 & 0.00 & 0.00 & 0.01 & 0.00 & 0.00 \\
\hline V10 & 0.10 & 0.52 & 0.15 & 0.02 & 0.00 & 0.00 & 0.00 & 0.03 & 0.04 & 0.07 & 0.00 & 0.04 & 0.00 & 0.01 & 0.01 & 0.00 & 0.00 \\
\hline V11 & 0.19 & 0.31 & 0.01 & 0.00 & 0.00 & 0.28 & 0.01 & 0.16 & 0.00 & 0.03 & 0.00 & 0.00 & 0.00 & 0.00 & 0.00 & 0.00 & 0.00 \\
\hline V12 & 0.67 & 0.13 & 0.08 & 0.06 & 0.00 & 0.00 & 0.01 & 0.00 & 0.00 & 0.02 & 0.01 & 0.00 & 0.00 & 0.0 & 0.00 & 0.01 & 0.00 \\
\hline V13 & 0.68 & 0.06 & 0.11 & 0.06 & 0.00 & 0.01 & 0.00 & 0.00 & & 0.00 & 0.00 & 0.03 & 0.02 & 0.0 & 0.00 & 0.00 & 0.00 \\
\hline V14 & 0.70 & 0.07 & 0.07 & 0.06 & 0.00 & 0.00 & 0.00 & 0.01 & 0.03 & 0.00 & 0.00 & 0.00 & 0.04 & 0.02 & 0.00 & 0.00 & 0.00 \\
\hline
\end{tabular}

Values in bold correspond for each variable to the factor for which the squared cosine is the largest

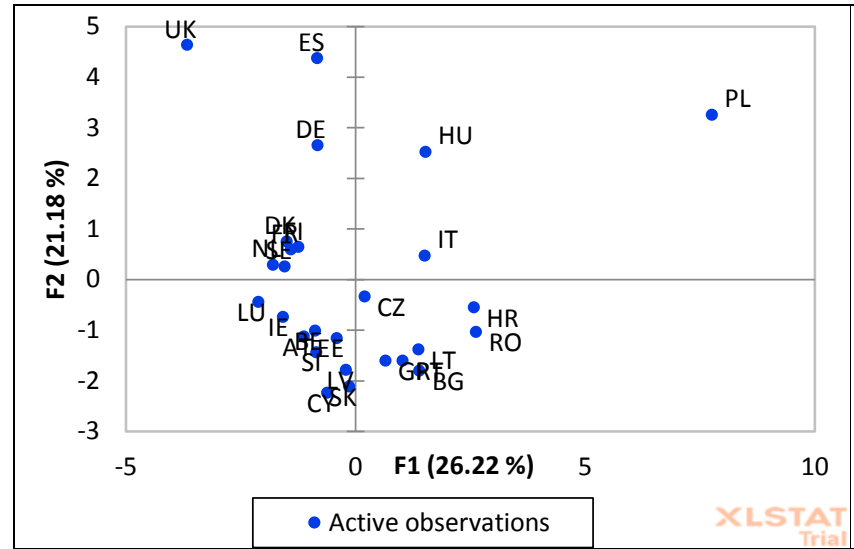

Figure 6. Diagram of the contribution of observations (axes F1 and F2: $47.39 \%$ )

Source: Authors' own research

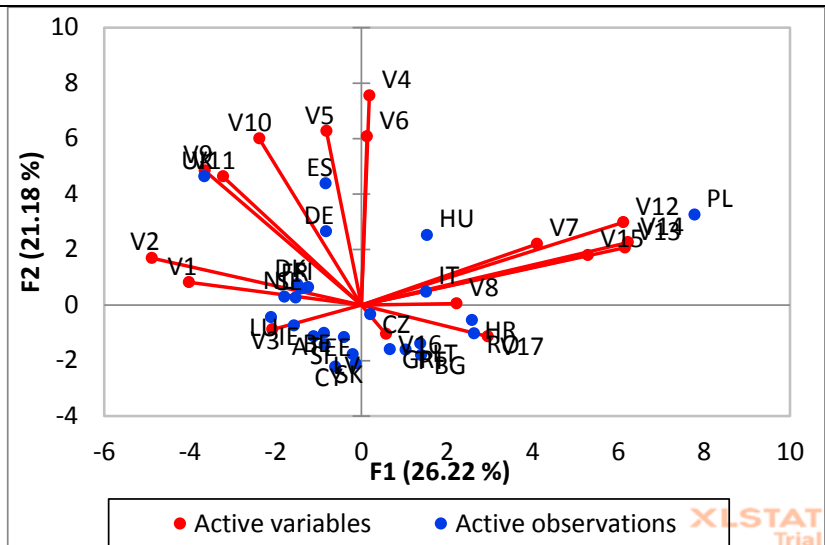

Figure 7. Diagram of the contribution of observations and variables (axes F1 and F2: $47.39 \%$ ) Source: Authors' own research 
Table 5. ACP - Matrix obtained from the Varimax rotation

\begin{tabular}{llr}
\hline & D1 & D2 \\
\hline D1 & 0.961 & -0.277 \\
D2 & 0.277 & 0.961 \\
\hline
\end{tabular}

Table 6. ACP - Factor loading after Varimax rotation

\begin{tabular}{lrr}
\hline & \multicolumn{1}{c}{ D1 } & \multicolumn{1}{c}{ D2 } \\
\hline V1 & -0.492 & 0.245 \\
V2 & -0.575 & 0.379 \\
V3 & -0.298 & -0.025 \\
V4 & 0.276 & 0.868 \\
V5 & 0.104 & 0.757 \\
V6 & 0.220 & 0.700 \\
V7 & 0.603 & 0.103 \\
V8 & 0.288 & -0.076 \\
V9 & -0.310 & 0.698 \\
V10 & -0.107 & 0.784 \\
V11 & -0.262 & 0.657 \\
V12 & 0.888 & 0.119 \\
V13 & 0.863 & 0.011 \\
V14 & 0.878 & 0.030 \\
V15 & 0.742 & 0.012 \\
V16 & 0.039 & -0.143 \\
V17 & 0.343 & -0.241 \\
\hline
\end{tabular}

Table 7. ACP - The variance explained after the rotation of the factors

\begin{tabular}{|c|c|c|c|c|c|}
\hline & D1 & D2 & F3 & F4 & F5 \\
\hline Variability (\%) & 25.831 & 21.564 & 13.780 & 9.572 & 6.617 \\
\hline Cumulative \% & 25.831 & 47.395 & 61.175 & 70.747 & 77.364 \\
\hline
\end{tabular}

Table 8. ACP - The contribution of variables to the formation of factors

\begin{tabular}{|c|c|c|c|c|c|c|}
\hline Code & Variables & D1 & D2 & F3 & F4 & F5 \\
\hline V1 & Real GDP / capita index, $($ EU28 = 100) & 5.502 & 1.636 & 6.431 & 0.578 & 31.148 \\
\hline V2 & $\begin{array}{l}\text { Participation rate in education and training (\% of the population aged } 25-64 \\
\text { participating in formal and non-formal education in the last } 12 \text { months) }\end{array}$ & 7.528 & 3.910 & 6.442 & 5.278 & 1.076 \\
\hline V3 & Absorption rate of EU states EU funds $2007-2013$ & 2.028 & 0.018 & 7.180 & 4.464 & 17.613 \\
\hline V4 & Total number of newly created jobs & 1.737 & 20.571 & 0.326 & 3.070 & 4.709 \\
\hline V5 & Number of jobs created in research & 0.247 & 15.634 & 0.094 & 8.520 & 6.713 \\
\hline V6 & Number of jobs created in SMEs (full-time equivalent) & 1.103 & 13.380 & 0.468 & 5.441 & 0.182 \\
\hline V7 & Number of jobs created in tourism & 8.271 & 0.289 & 1.355 & 16.125 & 0.096 \\
\hline V8 & Number of students who received funding & 1.891 & 0.159 & 8.718 & 18.525 & 11.280 \\
\hline V9 & Number of enterprises that received support & 2.187 & 13.295 & 0.812 & 11.116 & 9.056 \\
\hline V10 & Number of cooperation projects between enterprises and research institutions & 0.262 & 16.777 & 6.441 & 1.413 & 0.005 \\
\hline V11 & Number of start-ups supported & 1.563 & 11.774 & 0.201 & 0.117 & 0.292 \\
\hline V12 & Newly built roads $(\mathrm{km})$ & 17.939 & 0.384 & 3.471 & 3.684 & 0.025 \\
\hline V13 & New TEN roads built $(\mathrm{km})$ & 16.941 & 0.004 & 4.613 & 3.461 & 0.009 \\
\hline V14 & Rehabilitated roads $(\mathrm{km})$ & 17.538 & 0.025 & 2.765 & 3.374 & 0.001 \\
\hline V15 & Additional renewable energy production capacity & 12.548 & 0.004 & 0.279 & 0.071 & 17.541 \\
\hline V16 & Unemployment rate $(\%)$ & 0.034 & 0.555 & 21.260 & 14.484 & 0.120 \\
\hline V17 & $\begin{array}{l}\text { Young people aged between } 15 \text { and } 24 \text { are not employed, nor in education and } \\
\text { training (NEET), annual averages }\end{array}$ & 2.682 & 1.588 & 29.144 & 0.276 & 0.134 \\
\hline
\end{tabular}

Table 9. ACP - The coefficients used in the construction of IMIPC

\begin{tabular}{|l|l|c|}
\hline Code & \multicolumn{1}{|c|}{ Variables } & Coefficients \\
\hline V1 & Real GDP / capita index, (EU28 =100) & 0.091 \\
\hline V2 & $\begin{array}{l}\text { Participation rate in education and training (\% of the population aged 25-64 participating in formal and non- } \\
\text { formal education in the last 12 months) }\end{array}$ & 0.048 \\
\hline V3 & Absorption rate of EU states EU funds 2007-2013 & 0.063 \\
\hline V4 & Total number of newly created jobs & 0.061 \\
\hline V5 & Number of jobs created in research & 0.062 \\
\hline V6 & Number of jobs created in SMEs (full-time equivalent) & 0.041 \\
\hline V7 & Number of jobs created in tourism & 0.052 \\
\hline V8 & Number of students who received funding & 0.081 \\
\hline V9 & Number of enterprises that received support & 0.073 \\
\hline V10 & Number of cooperation projects between enterprises and research institutions & \\
\hline
\end{tabular}




\begin{tabular}{|l|l|r|}
\hline \hline Code & \multicolumn{1}{|c|}{ Variables } & Coefficients \\
\hline V11 & Number of start-ups supported & 0.028 \\
\hline V12 & Newly built roads (km) & 0.051 \\
\hline V13 & New TEN roads built (km) & 0.050 \\
\hline V14 & Rehabilitated roads (km) & 0.047 \\
\hline V15 & Additional renewable energy production capacity & 0.061 \\
\hline V16 & Unemployment rate (\%) & 0.073 \\
\hline V17 & Young people aged between 15 and 24 are not employed, nor in education and training (NEET), annual averages & 0.068 \\
\hline
\end{tabular}

Table 10. ACP - Grouping EU countries according to IMIPC and SPI values

\begin{tabular}{|c|c|c|c|c|c|}
\hline \multicolumn{3}{|c|}{ IMIPC Class } & \multicolumn{3}{|c|}{ SPI Class } \\
\hline 1 & 2 & 3 & 1 & 2 & 3 \\
\hline Poland & United Kingdom & Croatia & Germany & Poland & Hungary \\
\hline Germany & Sweden & Belgium & Netherlands & Czech Republic & Romania \\
\hline Netherlands & Spain & Portugal & Denmark & Italy & Bulgaria \\
\hline Denmark & Finland & Slovenia & United Kingdom & Lithuania & Latvia \\
\hline Hungary & Czech Republic & Estonia & Sweden & Croatia & Slovakia \\
\hline & Luxembourg & Romania & Spain & Portugal & Cyprus \\
\hline & Austria & Greece & Finland & Slovenia & \\
\hline & Italy & Bulgaria & Luxembourg & Estonia & \\
\hline & Ireland & Latvia & Austria & Greece & \\
\hline & Lithuania & Slovakia & Ireland & & \\
\hline & France & Cyprus & France & & \\
\hline & & & Belgium & & \\
\hline
\end{tabular}

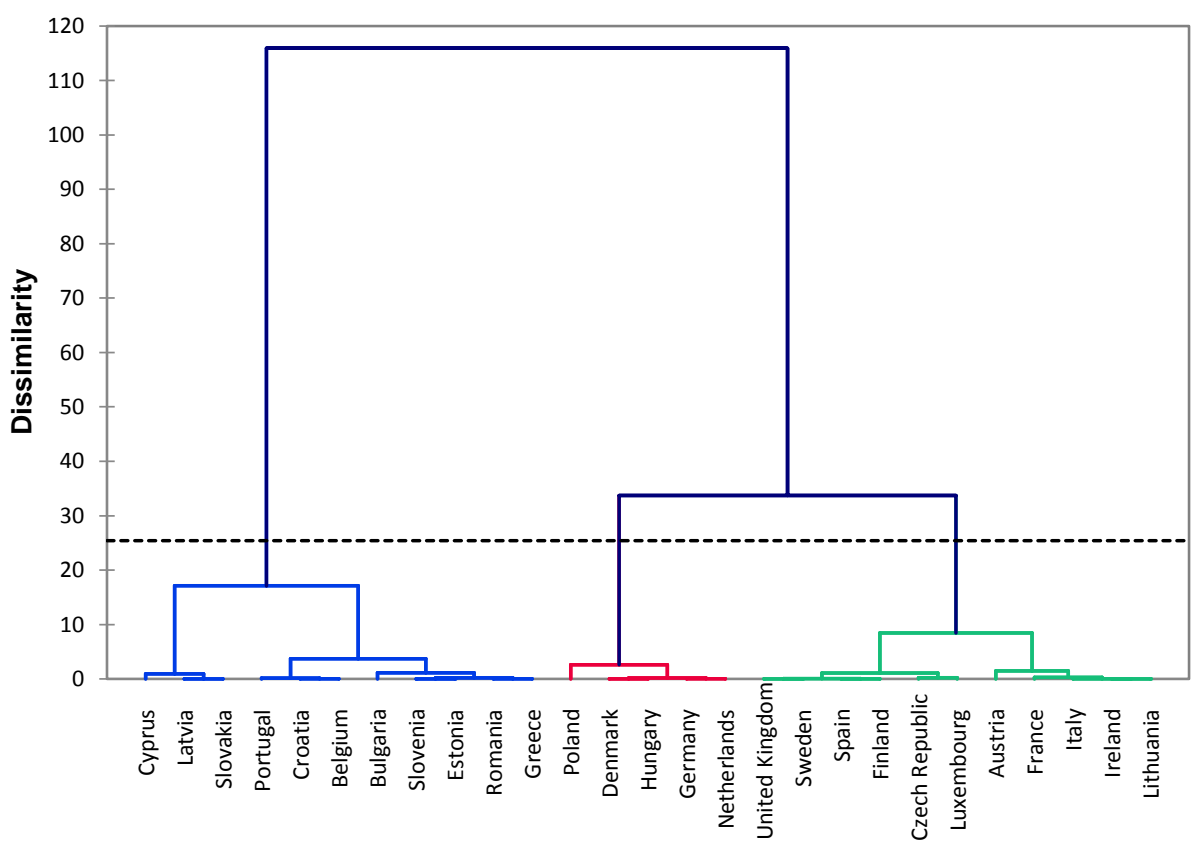

Figure 8. Clusters obtained according to the CPI value for EU Member States Source: Authors' own research 


\section{Annex 2}

\section{Validity testing}

Table 11. Correlation matrix

\begin{tabular}{|c|c|c|c|c|c|}
\hline \multicolumn{3}{|c|}{ Correlation matrix (Spearman): } & \multicolumn{3}{|c|}{ p-values (Spearman): } \\
\hline Variables & IMIPC & 2016 & Variables & IMIPC & 2016 \\
\hline IMIPC & 1 & -0.676 & IMIPC & 0 & 0.000 \\
\hline 2016 & -0.676 & 1 & 2016 & 0.000 & 0 \\
\hline $\begin{array}{l}\text { Values in bold are c } \\
\text { alpha }=0.05\end{array}$ & with a signific & & & & \\
\hline
\end{tabular}

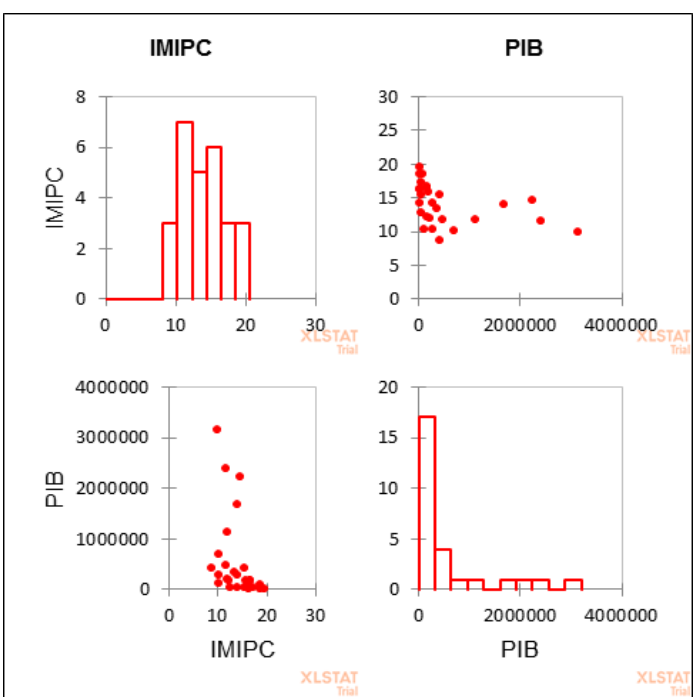

Figure 9. Distribution and correlation of variables before logarithm Source: Authors' own research

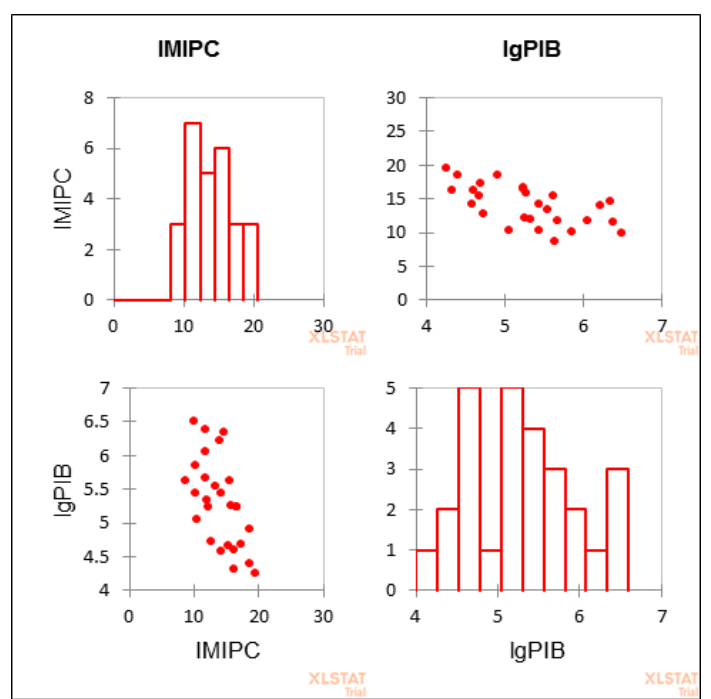

Figure 10. Distribution and correlation of variables by logarithm

Source: Authors' own research

Shapiro-Wilk test (IgPIB):

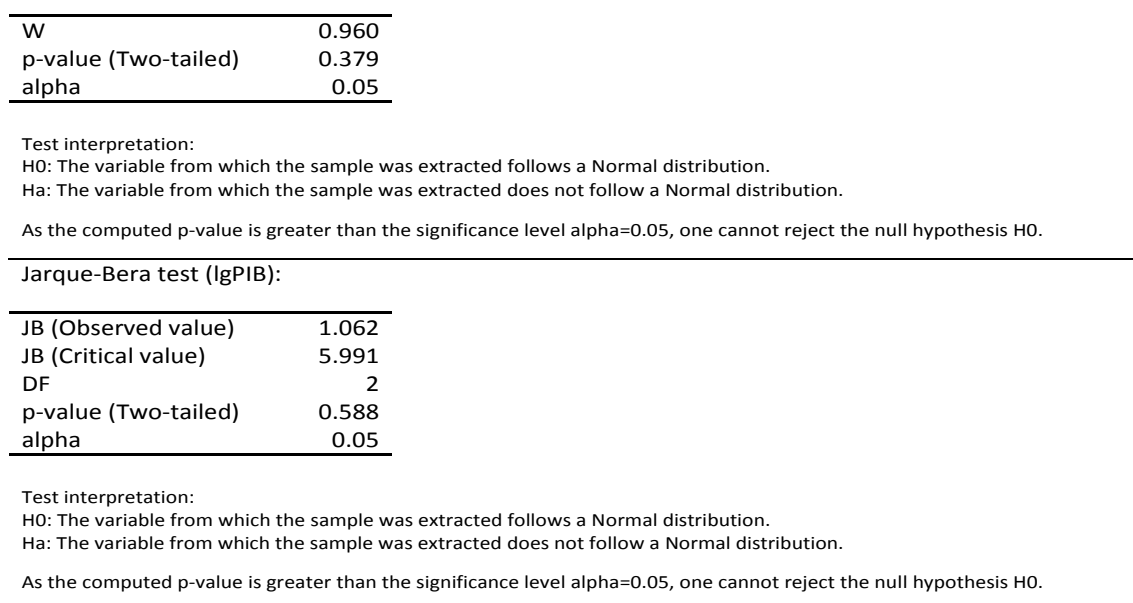

Figure 11. Output normality testing

Source: Authors' own research 
Correlation matrix (Pearson):

\begin{tabular}{lrr}
\hline & \multicolumn{3}{c}{ Variables } & IMIPC & \multicolumn{1}{c}{ IgPIB } \\
\hline IMIPC & $\mathbf{1}$ & $-\mathbf{0 . 6 0 9}$ \\
IgPIB & $-\mathbf{0 . 6 0 9}$ & $\mathbf{1}$ \\
\hline \multicolumn{2}{l}{ Values in bold are different from 0 with a significance level } \\
alpha $=0.05$
\end{tabular}

p-values (Pearson):

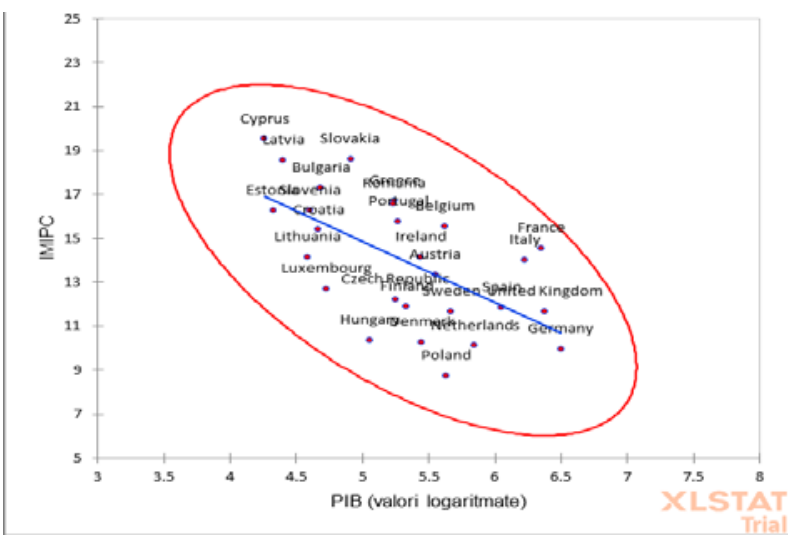

\begin{tabular}{lrr}
\hline Variables & IMIPC & \multicolumn{1}{c}{ IgPIB } \\
\hline IMIPC & $\mathbf{0}$ & $\mathbf{0 . 0 0 1}$ \\
IgPIB & $\mathbf{0 . 0 0 1}$ & $\mathbf{0}$ \\
\hline
\end{tabular}

Figure 12. IMIPC / lgPIB correlation analysis

Source: Authors' own research

\begin{tabular}{|c|c|c|c|c|c|c|c|}
\hline \multicolumn{8}{|c|}{ Goodness of fit statistics (IMIPC): } \\
\hline Observations & & & & & & & \\
\hline Sum of weights & & & & & & & \\
\hline DF & & & & & & & \\
\hline $\mathrm{R}^{2}$ & & & & & & & \\
\hline Adjusted $\mathrm{R}^{2}$ & & & & & & & \\
\hline MSE & & & & & & & \\
\hline RMSE & & 88 & & & & & \\
\hline MAPE & & & & & & & \\
\hline DW & & 03 & & & & & \\
\hline $\mathrm{Cp}$ & & & & & & & \\
\hline AIC & & & & & & & \\
\hline SBC & & & & & & & \\
\hline PC & & & & & & & \\
\hline \multicolumn{8}{|c|}{ Analysis of variance (IMIPC): } \\
\hline Source & $\mathrm{DF}$ & Sum of $s$ & uares & Mean square & & $\operatorname{Pr}>\mathrm{F}$ & \\
\hline Model & 1 & & 84.125 & 84.1 & & 14.755 & \\
\hline Error & 25 & & 142.539 & 5.7 & 702 & & \\
\hline Corrected Total & 26 & & 226.663 & & & & \\
\hline \multicolumn{8}{|c|}{ Computed against model $Y=$ Mean $(Y)$} \\
\hline \multicolumn{8}{|c|}{ Model parameters (IMIPC): } \\
\hline Source $\quad$ Value & & ird error & $\mathrm{t}$ & $\operatorname{Pr}>|t|$ & Lowe & $r$ bound $(95 \%)$ & Upper bound (95\%) \\
\hline \multirow{2}{*}{$\begin{array}{l}\text { Intercept } \\
\text { IgPIB } \\
\end{array}$} & & 3.839 & 7.461 & $<0.0001$ & & 20.733 & 36.545 \\
\hline & & 0.718 & -3.841 & 0.001 & & -4.239 & -1.280 \\
\hline \multicolumn{8}{|c|}{ Equation of the model (IMIPC): } \\
\hline \multicolumn{8}{|c|}{$I M I P C=28.639-2.760 * \lg P I B$} \\
\hline \multicolumn{8}{|c|}{ Standardized coefficients (IMIPC): } \\
\hline $\begin{array}{ll}\text { Source } & \text { Value } \\
\end{array}$ & Stan & d error & $\mathrm{t}$ & $\operatorname{Pr}>|t|$ & Low & bound $(95 \%)$ & Upper bound (95\%) \\
\hline-0.609 & & 0.159 & -3.841 & 0.001 & & -0.936 & -0.283 \\
\hline
\end{tabular}

Figure 13. Output regression Source: Authors' own research

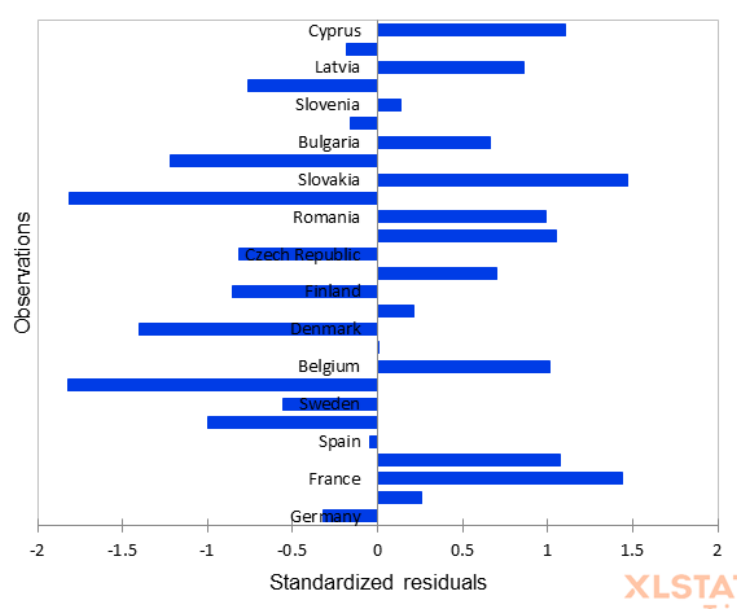

Figure 14. Standardized residue output Source: Authors' own research 